\title{
The Unsung Heroines of India's Freedom Struggle
}

\author{
Zahied Rehman Ganie \\ Lecturer \\ History Government Degree College Bijbehara, Anantnag, Kashmir, India \\ E-mail: bazmazahied@gmail.com \\ Shanti Dev Sisodia $P h D$ \\ Associate Professor \\ Department of Ancient Indian History Culture and Archaeology \\ Jiwaji University Gwalior M.P., India \\ E-mail: jusisodia@gmail.com
}

\begin{abstract}
"When woman, whom we call Abala becomes Sabala, all those who are helpless will become powerful." $\sim$ Mahatma Gandhi
\end{abstract}

\begin{abstract}
The history of Indian Freedom Struggle would be incomplete without mentioning the contribution of women. The sacrifice made by the women of India will occupy the foremost place. They fought with true spirit and undaunted courage and faced various tortures, exploitations and hardships to earn us freedom. When most of the men freedom fighters were in prison the women came forward and took charge of the struggle. The list of great women whose names have gone down in history for their dedication and undying devotion to the service of India is a long one. Woman's participation in India's freedom struggle began as early as in 1817. Bhima Bai Holkar fought bravely against the British colonel Malcolm and defeated him in guerilla warfare. Many women including Rani Channama of Kittur, Rani Begum Hazrat Mahal of Avadh fought against British East India company in the 19th century; 30 years before the "First War of Independence I857" The role played by women in the War of Independence (the Great Revolt) of 1857 was creditable and invited the admiration even leaders of the Revolt. Rani of Ramgarh, Rani Jindan Kaur, Rani Tace Bai, Baiza Bai, Chauhan Rani, Tapasvini Maharani daringly led their troops into the battlefield. Rani Lakshmi Bai of Jhansi whose heroism and superb leadership laid an outstanding example of real patriotism .Indian women who joined the national movement belonged to educated and liberal families, as well as those from the rural areas and from all walk of life, all castes, religions and communities. Sarojini Naidu, Kasturba Gandhi, Vijayalakmi Pundit and Annie Besant in the 20th century are the names which are remembered even today for their singular contribution both in battlefield and in political field.
\end{abstract}

Keywords: Women, Freedom Struggle, Sacrifice, Heroism, Rani Laxmi Bai, Bhima Bai Holkar, Keladi Chennamma, Avanti Bai, Beza Bai, Begum Hazrat Mahal.

\section{Introduction}

Woman's participation in India's freedom struggle started as ahead of schedule as in I817. Bhima Bai Holkar battled intrepidly against the British Colonel Malcolm and vanquished him in guerrilla warfare. Rani Lakshmi Bai of Jhansi whose bravery and brilliant leadership laid on remarkable case of genuine patriotism. Sarojini Naidu, Kasturba Gandhi , Vijay Lakshmi savant, Annie Besant and so on in the twentieth century are the names which are recalled even today for their particular contribution in the freedom struggle of India.

\section{Data Analysis}

Let us elucidate the role of Indian women who participated in the freedom struggle against British East India Company and British Empire and made great and rich contributions in various ways.

Bhima Bai Holkar : (17 Sep.1795-28 Nov.1858)

Bhima Bai Holkar, born on 17 September 1795 was the daughter of Yashwant Rao Holkar, the Maharaja of Indore. In I8I7, Bhima Bai fought bravely against the British colonel Malcolm and defeated him in guerilla warfare. At the Battle of Mahidpur, 
she led a brigade of 2,500 cavalry, sword and lance in hand, into the battle against the British at Mahidpur. It is believed that her act of taking on the East India Company as a soldier inspired Rani Lakshmi Bai of Jhansi in I858 during the Indian Rebellion of 1857. She died at Indore, 28 November I858 (Basu, I976).

\section{Keladi Chennamma: (23 Oct.I778-2 Feb. I829)}

Chennamma was an Indian revolutionary, freedom fighter and Rani of the Kittur, a former princely state in Karnataka. She led an armed force against the British East India Company in I824 in defiance of the doctrine of lapse in an attempt to maintain Indian control over the region, but was defeated in the third war and died imprisoned. She was one of the first female rulers to rebel against British rule (Thilagavathi \& Thilagavathi ,2009).

Rani Chennamma was born on 23 October 1778, in Kakati, a small village in the present Belagavi District of Karnataka. She married Raja Mallasarja of the Desai family at the age of I5.

Chennamma's husband died in 1824, leaving her with a son and a state full of volatility. This was followed by her son's death in 1824. Rani Chennamma was left with the state of Kittur and an uphill task to save it from the British. Following the death of her husband and son, Rani Chennamma adopted Shivalingappa in the year I824 and made him the heir to the throne. This irked the East India Company, who ordered Shivalingappa's expulsion, on the pretext of the Doctrine of Lapse.

Rani Chennamma sent a letter to Mount Stuart Elphinstone, Lieutenant-Governor of the Bombay Presidency pleading her cause, but the request was turned down, and war broke out. In the first round of war, during October I824, British forces lost heavily and St John Thackeray, collector and political agent, was killed in the war. Amateur Balappa, a lieutenant of Chennamma, was mainly responsible for his killing and losses to British forces. Two British officers, Sir Walter Elliot and Mr. Stevenson were also taken as hostages. Rani Chennamma released them with an understanding with Chaplin that the war would be terminated but Chaplin continued the war with more forces. During the second assault, Sub collector of Solapur, Mr. Munro, nephew of Thomas Munro was killed. Rani Chennamma fought fiercely with the aid of her lieutenant, Sangolli Rayanna, but was ultimately captured and imprisoned at Bailhongal Fort, where she died on 2 February I829 (Bhat, I998).

\section{Avanti Bai: (I6 Aug. I83I- 20 Mar. I858)}

Avanti Bai was a freedom fighter and queen of what is now Dindori in Madhya Pradesh, which in her time was called Ramgarh. Avanti Bai was the queen of Vikramaditya Singh of Ramgarh estate, which now lies in Dindori district, Madhya Pradesh. Upon the death of her husband in I85I, Avanti Bai attempted to act as regent for her son, Amar Singh, who was a minor. The British authorities did not accept this and the Court of Wards appointed an administrator to oversee his affairs. She threw the administrator out and declared war against the British.

When the revolt of 1857 broke out, Avanti Bai raised and led an army of 4000. Her first battle with the British took place in the village of Kheri near Mandla, where she and her army were able to defeat the British forces. However, stung by the defeat the British came back with vengeance and launched an attack on Ramgarh. Avanti Bai moved to the hills of Devharigarh for safety. The British army set fire to Ramgarh, and turned to Devharigarh to attack the queen (Gupta, 20I5).

Avanti Bai resorted to guerilla warfare to fend of the British army but committed suicide with her sword on 20 March I858 when facing almost certain defeat in battle.

\section{Baiza Bai: (I784-I863)}

Baiza Bai was born in Kagal, Kolhapur, Maharashtra in I784. In February 1798 in Poona, at the age of I4, she was married to Daulat Rao Scindia, the ruler of Gwalior. She was known as a superb horsewoman, and had been trained to fight with a sword and spear. She accompanied her husband during the Maratha wars with the British, and she fought against Arthur Wellesley, the future Duke of Wellington, at the Battle of Assaye (Farooqui, 2000).

Baiza Bai appears to have adopted her father's anti-British stance in her younger days. During the British campaign against the Pindaris, she had urged her husband to support the Peshwa Baji Rao II against them. When Daulat Rao submitted to British demands, she even left him briefly, accusing him of cowardice. She was also fiercely opposed to the Scindia surrender of Ajmer to the British. Baiza Bai died in Gwalior in I863 (Farooqui, 20I I).

\section{Kanaklata Barua: ( 22 Dec. 1924- 1942)}

Barua was born in the Borangabari village of the Darrang district of Assam as the daughter of Krishna Kanta and Karneshwari Barua. Kanaklata Barua was also called Birbala and Shaheed (martyr). During Quit India Movement (I942) she joined the Mrityu Bahini (death squad) which was formed by the youth of Gohpur sub-division of Assam. On 20 September I942, the Bahini decided it would hoist the national flag at the local police station. A procession of unarmed villagers were led by Barua to do so. The police under Rebati Mahan Som the officer in-charge of the police station warned the procession of dire 
consequences if they proceeded with their plan. Undeterred by the police, the procession continued marching ahead when the police fired upon the procession. Barua was shot and the flag she was carrying with her was taken up by Mukunda Kakoti who too was shot at. Both Barua and Kakoti were killed in the police action. Barua was only I7 years of age at the time of her martyrdom (Pathak, 2008).

\section{Rani Abbaka Chowta: (I525-I570).}

Rani Abbakka from Chowta dynasty ruled a small coastal town called Ullal, $8 \mathrm{~km}$ away from Mangalore. During her reign, the Portuguese wanted to conquer the coastal town and use it as a port. They made their first attempt in I525. But Rani Abbakka resisted and fought fiercely against the Portuguese, gaining the name Rani Abhaya (fearless queen) (Shintri \& Rao, I983).

\section{Bina Das: (24 Aug. I9II-26 Dec.I986)}

Bina was an Indian revolutionary and nationalist from West Bengal. She was the daughter of a well-known Brahmo teacher, Beni Madhab Das and a social worker, Sarala Devi. Her elder sister Kalyani Das (Bhattacharyee) was also a freedom fighter.

Bina Das was a member of Chhatri Sangha, a semi-revolutionary organisation for women in Kolkata. On 6 February 1932, she attempted to assassinate the Bengal Governor Stanley Jackson, in the Convocation Hall of the University of Calcutta. The revolver was supplied by another freedom fighter Kamala Das Gupta. She fired five shots but failed and was sentenced to nine years of rigorous imprisonment.

After her early release in 1939, Das joined the Congress party. In 1942, she participated in the Quit India movement and was imprisoned again from 1942-45. From 1946-47, she was a member of the Bengal Provincial Legislative Assembly and, from 1947-5I, of the West Bengal Legislative Assembly. After the death of her husband, she led a lonely life in Rishikesh and died in anonymity. Her dead body was recovered from the roadside in 26 December 1986 in a partially decomposed state (Radha, 1997).

\section{Pritilata Waddedar: (05 May I9II- 23 Sep. I932)}

Pritilata was born in a middle-class Vaidya (Baidya) family on 5 May I9II in Dhalghat village in Patiya upazila of Chittagong (now in Bangladesh).She decided to join the Indian independence movement. Surya Sen had heard about her and wanted her to join their revolutionary group. On I3 June 1932, Pritilata met Surya Sen and Nirmal Sen in their Dhalghat camp. A contemporary revolutionary, Binod Bihari Chowdhury, objected that they did not allow women to join their group. However, Pritalata was allowed to join the group because the revolutionaries reasoned that women transporting weapons would not attract as much suspicion as men.

Pritilata joined a revolutionary group headed by Surya Sen. She is known for leading fifteen revolutionaries in the 1932 armed attack on the Pahartali European Club, during which one person was killed and eleven injured. The revolutionaries torched the club and were later caught by the British police. To avoid arrest, Pritilata consumed cyanide and died (Forbes, 1999).

\section{Rani Gaidinliu: (26 Jan.I9I5-I7 Feb.I993)}

Gaidinliu was born on 26 January I9I5 at Nungkao (or Longkao) village in the present-day Tousem sub-division of Tamenglong District, Manipur. She was from the Rongmei Naga tribe (also known as Kabui. At the age of I3, she joined the Heraka religious movement of her cousin Haipou Jadonang. The movement later turned into a political movement seeking to drive out the British from Manipur and the surrounding Naga areas (Nag, 1976).

Gaidinliu was arrested in 1932 at the age of 16, and was sentenced to life imprisonment by the British rulers. Jawaharlal Nehru met her at Shillong Jail in 1937, and promised to pursue her release. Nehru gave her the title of "Rani" ("Queen"), and she gained local popularity as Rani Gaidinliu. After the Interim Government of India was set up in I946, Rani Gaidinliu was released on Prime Minister Nehru's orders from Tura jail, having spent I4 years in various prisons. She continued to work for the upliftment of her people. An advocate of the ancestral Naga religious practices, she staunchly resisted the conversion of Nagas to Christianity. She was honoured as a freedom fighter and was awarded a Padma Bhushan by the Government of India in I982.

2002).

In I991, Gaidinliu returned to her birthplace Longkao, where she died on I7 February 1993 at the age of 78 (Nayya,

\section{Kalpana Datta: (27 July I9I3-08 Feb.I995)}

Kalpana Datta (later Kalpana Joshi) was born at Sripur, a village in the Chittagong District in the Bengal Province of British India on 27 July 1913. After passing her matriculation examination in 1929 from Chittagong, she went to Calcutta and joined 
the Bethune College for graduation in Science. Soon, she joined the Chhatri Sangha (Women Students Association), a semirevolutionary organisation in which Bina Das and Pritilata Waddedar were also active member's.

The Chittagong armoury raid was carried out on 18 April 1930. Kalpana joined the "Indian Republican Army, Chattagram branch", the armed resistance group led by Surya Sen in May I93I (Chandra \& Bipin, I998).

In September, I93I Surya Sen entrusted her along with Pritilata Waddedar to attack the European Club in Chittagong. But a week before the attack, she was arrested while carrying out reconnaissance of the area. She went underground after her release on bail. On I7 February 1933 the police encircled their hiding place in Gairila village, and that raid Surya Sen was arrested but Kalpana was able to escape from there. She was finally arrested on I9 May 1933. In the second supplementary trial of the Chittagong armoury raid case, Kalpana was sentenced to transportation for life. She was released in I939.

Kalpana Datta graduated from the Calcutta University in 1940 and joined the Communist Party of India. She served as a relief worker during the 1943 Bengal famine and during the Partition of Bengal. In I946, she contested in the elections for the Bengal Legislative Assembly as a Communist Party of India candidate from Chittagong but could not win.

Later, she joined the Indian Statistical Institute where she worked until her retirement. She died in Calcutta on 8 February 1995 (Simmi, 2003).

\section{Rani Lakshmi Bai: (19 November I828 - I8 June I858)}

\section{बुंदेले हरबोलों के मुँह हमने सुनी कहानी थी, खूब लड़ी मर्दानी वह तो झाँसी वाली रानी थी। \\ Bundeley Harbolon Ke Mooh Humney Suni Kahani Thi, Khoob Ladi Mardani Wo To Jhansi Wali Rani Thi.}

(From the bards of Bundela we have heard this story,

She fought valiantly like a man, she was the queen of Jhansi) (Subhadra Kumari, 1930)

$$
\sim \text { Subhadra Kumari Chauhan }
$$

"She was the bravest and best military leader of the rebels. A man among mutineers,"

$$
\sim \text { Hugh Rose. }
$$

Rani Lakshmi Bai was born on 19 November 1828 in the town of Varanasi into a Marathi Karhade Brahmin family. She was named Manikarnika Tambe and was nicknamed Manu. Her father was Moropant Tambe and her mother Bhagirathi Sapre (Bhagirathi Bai). Her parents came from Maharashtra.

Manikarnika was married to the Maharaja of Jhansi, Gangadhar Rao Newalkar, in May 1842 and was afterwards called Lakshmi Bai (or Laxmibai) in honour of the Hindu goddess Lakshmi and according to the traditions. She gave birth to a boy, later named Damodar Rao, in I85I, who died after four months. The Maharaja adopted a child called Anand Rao, the son of Gangadhar Rao's cousin, who was renamed Damodar Rao, on the day before the Maharaja died. The adoption was in the presence of the British political officer who was given a letter from the Maharaja instructing that the child be treated with respect and that the government of Jhansi should be given to his widow for her lifetime (Thomas, I860).

After the death of the Maharaja in November I853, because Damodar Rao (born Anand Rao) was an adopted son, the British East India Company, under Governor-General Lord Dalhousie, applied the Doctrine of Lapse, rejecting Damodar Rao's claim to the throne and annexing the state to its territories. When she was informed of this she cried out "I shall not surrender my Jhansi" (Main apni Jhansi nahi doongi). In March 1854, Rani Lakshmi Bai was given an annual pension of Rs. 60,000 and ordered to leave the palace and the fort. But she refused to surrender Jhansi and fought valiantly against the British general Hugh Rose in the first war of Independence. After unsuccessfully defending Jhansi she fled to Gwalior and died in the course of the battle on I8 June I858

near Kotah-ki-Serai (Nigel, 2009).

Twenty years after her death Colonel Malleson wrote in the "History of the Indian Mutiny; vol. 3; London, I878", 'Whatever her faults in British eyes may have been, her countrymen will ever remember that she was driven by ill-treatment into rebellion, and that she died for her country, We cannot forget her contribution for India (John \& Malleson, 20I0).

\section{Begam Hazrat Mahal: (1820-7 Apr. I879)}

Begum Hazrat Mahal also called as Begum of Awadh, was the second wife of Nawab Wajid Ali Shah the Nawab of Awadh. The British annexed Awadh in 1856 on the pretext of Maladministration and Wajid Ali Shah was exiled to Calcutta. During 
the Indian Mutiny, from I857 to I858, Begum Hazrat Mahal's band of supporters, led by Raja Jailal Singh, rebelled against the forces of the British; later, they seized control of Lucknow and she declared her son, Birjis Qadar, as the ruler (Wali) of Oudh (Dalrymple, 2006).

One of the principal complaints of Begum Hazrat Mahal was that the East India Company had casually demolished Temples and mosques just to make way for roads.

When the forces under the command of the British re-captured Lucknow and most of Awadh, she was forced to retreat. Hazrat Mahal worked in association with Nana Sahib, but later joined the Maulavi of Faizabad in the attack on Shahjahanpur.

Ultimately, she had to retreat to Nepal, where she was initially refused asylum by Jang Bahadur, but was later allowed to stay. She died there in 1879 and was buried in a nameless grave in the grounds of Kathmandu's Jama Masjid. After her death, on the occasion of the jubilee of Queen Victoria (I887), the British Government pardoned Birjis Qadar and he was allowed to return home (Hibbert, I980).

To recognize her unlimited endeavours in battling for the freedom of nation, the Government of India issued a stamp on tenth May 1984. The Ministry of Minority Affairs, Government of India has started the Begum Hazrat Mahal National Scholarship for Meritorious Girls belonging to minority communities in India. This scholarship is implemented through the Maulana Azad Education Foundation (David, 2002).

\section{Annie Besant: (I Oct. I887-20 Sep.1933)}

Annie Besant born on I October 1847 Clapham, London, UK was a British socialist, theosophist, activist, writer, orator, educationist, and philanthropist. Regarded as a champion of human freedom, she was an ardent supporter of both Irish and Indian self-rule. As an educationist, her contributions included the founding of the Banaras Hindu University (Aparna., B, 1990).

In I893, soon after becoming a member of the Theosophical Society she went to India for the first time.

As early as 1902 Besant had written that "India is not ruled for the prospering of the people, but rather for the profit of her conquerors, and her sons are being treated as a conquered race.". She encouraged Indian national consciousness, attacked caste and child marriage, and worked effectively for Indian education. Along with her theosophical activities, Besant continued to actively participate in political matters.

In 1907 she became president of the Theosophical Society, (The Theosophical Society was an organization formed in the United States in 1875 by Helena Blavatsky to advance Theosophy.) whose international headquarters were, by then, located in Adyar, Madras, (Chennai) (Maitrayee, 20II).

In 1916 Besant launched the All India Home Rule League along with Lokmanya Tilak, once again modelling demands for India on Irish nationalist practices. This was the first political party in India to have regime change as its main goal. In June I9I7 Besant was arrested and interned at a hill station, where she defiantly flew a red and green flag. The Congress and the Muslim League together threatened to launch protests if she were not set free; Besant's arrest had created a focus for protest. Besant was freed in September 1917, and in December 1917, she took over as president of the Indian National Congress for a year (Bala, I986).

Besant edited two newspapers:

A) The Commonweal (a weekly dealing on Indian national issues), and

B) New India (a daily newspaper which was a powerful mouthpiece for I5 years advocating Home Rule and revolutionizing Indian journalism).

Besant died on 20 September 1933, at age 85, in Adyar, Madras.

\section{Usha Mehta: (25 Mar.I920-II Aug. 2000).}

Usha was born in Saras village near Surat, Gujarat on 25 March 1920. When she was just five years old, she first saw Mahatma Gandhi while on a visit to his ashram at Ahmedabad. Shortly afterwards, Gandhi arranged a camp near her village in which little Usha participated, attending sessions and doing a little spinning.

In 1928, eight-year-old Usha participated in a protest march against the Simon Commission and shouted her first words of protest against the British Raj: "Simon Go Back."

In 1932, when Usha was 12, her family moved to Bombay, making it possible for her to participate more actively in the freedom movement. She and other children distributed clandestine bulletins and publications, visited relatives in the prisons, and carried messages to these prisoners (Kaur, 20I3). 
Usha grew up highly influenced by Gandhi and became one of his followers. She made an early decision to remain celibate for life and took up a Spartan, Gandhian lifestyle, wearing only Khadi clothes and keeping away from luxuries of all types. Over time, she emerged as a prominent proponent of Gandhian thought and philosophy. She ended her studies in 1942 to join the Quit India Movement. Thereafter, beginning at age 22, she participated in the freedom movement full-time.

Gandhi and the Congress had announced that the Quit India Movement would commence on 9 August I942 with a rally at Gowalia Tank grounds in Mumbai. Nearly all leaders including Gandhi were arrested before that date. However, a vast crowd of Indians gathered at Gowalia Tank Ground on the appointed day. It was left to a group of junior leaders and workers to address them and hoist the national flag. Usha was one of those who hoisted the tricolour on 9 August I942 at Gowalia Tank Ground, which was later renamed "August Kranti Maidan" (Raju, 2004).

On I4 August 1942, Usha and some of her close associates began the Secret Congress Radio, a clandestine radio station. It went air on 27 August. The first words broadcast in her voice were:

\section{"This is the Congress Radio calling on 42.34 meters from somewhere in India."}

Her associates included Vithalbhai Jhaveri, Chandrakant Jhaveri, Babubhai Thakkar and Nanka Motwani, owner of Chicago Radio, who supplied equipment and provided technicians. Many other leaders, including Dr. Ram Manohar Lohia, Achyut Patwardhan and Purushottam Trikamdas, also assisted the Secret Congress Radio. The radio broadcast recorded messages from Gandhi and other prominent leaders across India. To elude the authorities, the organizers moved the station's location almost daily. Ultimately, however, the police found them on 12 November 1942 and arrested the organizers, including Usha Mehta. All were later imprisoned.

The Criminal Investigation Department (CID), a wing of the Indian Police, interrogated her for six months. After the trial, she was sentenced to four years imprisonment (I942 to 1946). Two of her associates were also convicted. Usha was imprisoned at Yeravada Jail in Pune. In March 1946, she was released, the first political prisoner to be released in Bombay, at the orders of Morarji Desai, who was at that time the home minister in the interim government.

Although the Secret Congress Radio functioned only for three months, it greatly assisted the movement by disseminating uncensored news and other information banned by the British-controlled government of India. Secret Congress Radio also kept the leaders of the freedom movement in touch with the public.

In August 2000, although she was suffering from fever, Usha participated like she did every year in the anniversary celebrations related to the Quit India Movement in August Kranti Maidan. She returned home weak and exhausted. Two days later, she died peacefully on I I August 2000 at the age of 80 (Padhy \& Rani, 2013).

\section{Conclusion}

Thus, from the above discussion it is clear that the history of freedom struggle is replete with the saga of sacrifice, bravery, selflessness and political sagacity of women. The history of Indian Freedom Struggle would be incomplete without mentioning the contribution made by these brave women. Many women assumed a gallant job in Indian freedom movement but unfortunately some of them are lost in the pages of history. Therefore, the need of the hour is to highlight the contribution made by these brave daughters of the soil in the freedom struggle of their motherland.

\section{References}

Aparna., B. (1990). The Role of Women in the Struggle for Freedom in B.R. Nanda, (eds.) Indian Women: From Purdah to Modernity, Radiant Publication, New Delhi, p.I9.

Bala., U. (1986). Indian Women Freedom Fighters I857-1947, Manmohan Publishers, New Delhi, p. 99.

Basu, A. (1976). Role of Women in Indian Struggle for Freedom, Vikas Publications, New Delhi. pp. $240-42$

Bhat, N. S. (1998). South Kanara, I799-1860: A Study in Colonial Administration and Regional Response. Mittal Publications.

Chandrababu, B. S., \& Thilagavathi, L. (2009). Woman, Her History and Her Struggle for Emancipation. Bharathi Puthakalayam.

Chandra \& Bipin. (1998). India's Struggle for Independence, New Delhi: Penguin Books, p.253

Dalrymple., W. (2006). The Last Mughal; the fall of a dynasty: Delhi, I857, Viking Penguin, p.69

David., S. (2002). The Indian Mutiny, Viking; p. 185

Farooqui, A. (2000). From Baiza Bai to Lakshmi Bai: The Scindia State in the Early Nineteenth Century and the Roots of I857'. Issues in Modern Indian History: For Sumit Sarkar, Popular Prakashan, Mumbai.

Farooqui, A. (201 I). Sindias and the Raj: Princely Gwalior C. I800-1850. Primus Books.

Forbes G. (1999). Women in Modern India. The New Cambridge History of India. IV.2. Cambridge University Press. pp. I40-I4I. 
Gupta, A. K. (20I5). Nineteenth-Century Colonialism and the Great Indian Revolt. Routledge.

Hibbert., C. (I980). The Great Mutiny, Harmondsworth: Penguin; p. 37 I

John., Kaye \& Malleson., G. B. (2010). History of the Indian Mutiny-I857-8. Cambridge University Press, Vol. 3; London, pp. 324-26.

Kaur., S. (2013). Role of women in India's struggle for freedom. International Journal of Management and Social Science Research Review, 2(4), II2.

Pathak, G. (2008). Assamese Women in Indian Independence Movement: With a Special Emphasis on Kanaklata Barua. Mittal Publications.

Padhy., S. C \& Rani., A. S. (2013)., Participation of Women in the Freedom Struggle during the Gandhian Era: A Comparative Study between Odisha and Andhra Pradesh. Odisha Review, I6-I8.

Radha, K. (1997). The History of Doing: An Illustrated Account of Movements for Women's Rights and Feminism in India I800-1990. Zubaan

Raju, V. R. (2004). Role of Women in Indian Freedom Struggle, Delhi.

Shintri, S., \& Rao, K. R. (I983). Women freedom fighters in Karnataka. Prasaranga, Karnatak University.

Simmi., Jain. (2003). Encyclopaedia of Indian Women through the Ages. Vol.3. Delhi: Kalpaz Publications. p. I06.

Subhadra Kumari.,C. (1930). Jhansi Ki Rani. Retrieved from https://www.poemhunter.com/subhadra-kumari-chauhan. Poem hunter.

Thomas., L. (I860). Central India during the Rebellion, cited in Edwardes, Michael (I975) Red Year. London: Sphere Books, p. II7

Maitrayee., C. (20II). The Indian Women's Movement: Reform and Revival. New Delhi: Palm Leaf Publications, Print.

Nag., A. K. (1976). Rani Gaidinliu: A Study of the Jadonang Movement of the Nagas. Tribal Mirror Publications. p. I8.

Nayya., K. (2002). Rani Gaidinliu. Ocean Books.

Nigel., A. (2009). Queen of Jhansi, Mumbai: Hollywood Publishing; p.5

\section{Copyrights}

Copyright for this article is retained by the author(s), with first publication rights granted to the journal. This is an open-access article distributed under the terms and conditions of the Creative Commons Attribution license (http://creativecommons.org/licenses/by/4.0/). 